\title{
ANALISIS FAKTOR PENYEBAB PERCERAIAN PADA MASA PANDEMI COVID-19 DI KABUPATEN BANYUMAS
}

\author{
Urip Tri Wijayanti ${ }^{*}$ \\ Perwakilan Badan Kependudukan dan Keluarga Berencana Nasional Provinsi Jawa Tengah, \\ Semarang 50139, Indonesia \\ *)E-mail: haidar1602@yahoo.co.id
}

\begin{abstract}
Abstrak
Tingkat perceraian di Kabupaten Banyumas pada masa pandemi Covid-19 dan menuju new normal tercatat mengalami peningkatan sebesar 48 kasus. Tujuan penelitian adalah untuk mengidentifikasi karakteristik dan faktor-faktor yang melatarbelakangi perceraian di masa pandemi Covid-19. Penelitian ini menggunakan pendekatan kuantitatif dengan desain cross-sectional study. Objek penelitian berupa data kasus perceraian bulan Maret s.d Juni 2020. Jumlah sampel sebanyak 200 responden yang dipilih menggunakan teknik simple random sampling. Metode analisis data menggunakan distribusi frekuensi dengan nilai modus untuk menentukan kecenderungan data. Hasil penelitian menemukan bahwa secara umum penggugat perceraian merupakan perempuan yang memiliki karakteristik berusia muda, berpendidikan rendah, tidak bekerja, usia perkawinan kurang dari lima tahun, dan baru memiliki satu anak. Faktor yang melatarbelakangi pasangan suami istri bercerai karena faktor ekonomi. Lebih lanjut, program yang dapat dikembangkan berdasarkan hasil penelitian yaitu perlu ada sosialisasi yang intens tentang persiapan kehidupan berkeluarga bagi calon pasangan muda khususnya dalam aspek ekonomi. Hal ini dimaksudkan agar para pasangan muda yang ingin memulai berkeluarga dapat membangun ketahanan keluarga yang optimal sehingga mampu mencegah terjadinya perceraian.
\end{abstract}

Kata kunci: faktor penyebab, identifikasi, karakteristik demografi, pandemi Covid-19, perceraian

\section{Analysis of the Factors Causing Divorce during the Covid-19 Pandemic in Banyumas District}

\begin{abstract}
Abstact
The divorce rate in Banyumas Regency during the Covid-19 pandemic was recorded to have increased by 48 cases. The research objective is to identify the characteristics and factors behind divorce during the Covid-19 pandemic. This study used a quantitative approach with a cross-sectional study design. The research object was data on divorce cases from March to June 2020. The total sample was 200 respondents who were selected using a simple random sampling technique. The data analysis method used a frequency distribution with the mode value to determine the data trend. The study results found that in general, divorce plaintiffs were women who had the characteristics of a young age, low education, unemployed, marriage age less than five years, and only had one child. The factors behind a husband and wife divorce were economic factors. Furthermore, programs that can be developed based on research results are intense socialization on family life preparation for potential young couples, especially in the economic aspect. This is intended so that young couples who want to start a family can build optimal family resilience to prevent divorce.
\end{abstract}

Keywords: causative factors, characteristics demography, divorce, identification, Covid-19 pandemic

\section{PENDAHULUAN}

Perceraian adalah pemutusan tali perkawinan karena suatu sebab yang disahkan oleh keputusan hakim atas tuntutan dari salah satu pihak atau kedua belah pihak (Simanjuntak, 2007). Perceraian terjadi karena ada suatu alasan yang melatarbelakanginya. Saat ini, kasus perceraian di Indonesia masih terjadi dan terus meningkat jumlahnya. Jumlah kasus perceraian juga mengalami peningkatan selama pandemi Covid-19. Berdasarkan data Mahkamah Agung, pendaftaran perceraian yang mulanya berjumlah 20 ribu kasus pada periode April dan Mei 2020 melonjak menjadi 57 ribu kasus pada Juni dan Juli 2020. Jika ditinjau lebih lanjut, peningkatan kasus perceraian yang paling banyak mengalami kenaikan adalah di Provinsi Jawa Tengah. Detik News (2020) melaporkan Provinsi Jawa Tengah sebagai wilayah yang paling banyak mengalami kenaikan kasus perceraian. 
Pandemi Covid-19 memiliki dampak yang besar dalam kehidupan keluarga. Untuk memutus penyebaran virus Covid-19 pemerintah menetapkan kebijakan Pembatasan Sosial Berskala Besar. Kebijakan ini menuntut keluarga untuk melakukan aktivitas dari rumah, mulai dari belajar, beribadah hingga bekerja. Keadaan ini membuat masing-masing anggota keluarga menghabiskan lebih banyak waktunya di rumah. Kondisi ini disikapi berbeda oleh tiaptiap keluarga. Ada yang menyikapinya dengan positif seperti membangun kembali kebersamaan dan kedekatan antar anggota keluarga. Namun, ada juga yang menyikapinya secara negatif hingga berujung pada konflik. Adapun aspek yang paling banyak menjadi bahan perdebatan antar pasangan suami istri sekaligus menjadi sumber konflik yaitu dari sisi ekonomi.

Hasil penelitian BKKBN dan IPB (2020) mengungkapkan, pada masa pandemi Covid19 pola hidup keluarga dalam bidang ekonomi, pekerjaan, hingga keturcukupan kebutuhan primer semakin memburuk. Penelitian di Cina juga menunjukkan hasil yang sama bahwa pada fase awal pandemi Covid-19 lebih dari separuh masyarakat mengalami dampak psikologis berupa stres, kecemasan, dan depresi dari tingkat sedang hingga berat ( $\mathrm{CaO}$ et al., 2020). Begitu pula penelitian Luo et al. (2020), salah satu penyebab kecemasan yang dialami para keluarga yaitu karena tidak stabilnya pendapatan. Banyak pasangan yang mengalami masa-masa sulit. Mereka tidak mampu mengelola stres dan menghadapi ketidakpastian serta kecemasan (Smyth et al., 2020). Hal ini memicu pada kekerasan instrumental yang diperparah dengan peningkatan penggunaan obat-obatan dan alkohol sebagai strategi untuk menghadapi tingkat stres yang luar biasa (Stanley \& Markman, 2020).

Perubahan ekonomi yang terjadi akibat pandemi Covid-19 tidak mampu diterima oleh semua keluarga. Ada keluarga yang tidak memiliki cukup tabungan untuk menghadapi kondisi darurat. Akhirnya konflik kerap terjadi, masing-masing memiliki keinginan serta gagasan yang ingin diakui dan dilaksanakan, sementara pihak lainnya memiliki harapan yang berbeda. Ego dan pengakuan tinggi kadang sulit dibendung di antara pasangan suami dan istri. Ada yang mampu mengatasi konflik tersebut dengan baik, namun ada juga yang membuat permasalahan tersebut semakin berlarut-larut. Hal menyebabkan ketahanan keluarganya menjadi lemah dan berakhir pada perceraian.
Bencana dan ketahanan keluarga menjadi hal yang tidak terpisahkan. Bencana dapat berdampak negatif pada keutuhan keluarga. Seperti hasil penelitian di Carolina Selatan yang menunjukkan bahwa perkawinan dan kelahiran menurun sementara perceraian meningkat di negara-negara yang terkena dampak badai hugo (Cohan \& Cole, 2002). Kemudian hasil penelitian di Taiwan, salah satu faktor risiko yang signifikan untuk depresi mayor akibat gempa adalah bercerai/janda (Chou et al., 2005). Lebih lanjut, survei di Austria tentang pandemi Covid-19 dan kualitas hubungan pasangan memberikan hasil bahwa individu dengan kualitas hubungan yang baik cenderung memiliki kesehatan mental yang positif dibandingkan individu dengan kualitas hubungan buruk atau tanpa hubungan (Pieh et al., 2020).

Berdasarkan data Pengadilan Agama Purwokerto dan Pengadilan Agama Banyumas (2019-2020), salah satu kabupaten yang mengalami peningkatan perceraian yakni Kabupaten Banyumas. Data Pengadilan Agama Kabupaten Banyumas mencatat pada bulan Juni 2020 sebagai bulan menuju new normal ada peningkatan sebesar 48 kasus dibandingkan keadaan normal bulan Januari 2020, bila jumlah tersebut disandingkan saat pandemi (Maret s.d. Mei) ada peningkatan sebanyak 464 kasus. Hal ini bermakna bahwa dalam satu hari ada sekitar 24 pasangan mendaftarkan perceraiannya. Bila dibandingkan tahun 2019 pada bulan yang sama, peningkatan hanya sekitar 83 kasus (Juni dibandingkan Maret s.d. Mei). Angka perceraian pada masa pandemi Covid-19 diduga pula karena adanya pembatasan sosial sehingga pengajuan perceraian menumpuk pada satu waktu. Hal itu dapat dilihat dari data bulan Maret sampai dengan Mei 2019, jumlah kasus perceraiannya di bawah jumlah kasus di bulan yang sama pada tahun 2020 (Gambar 1).

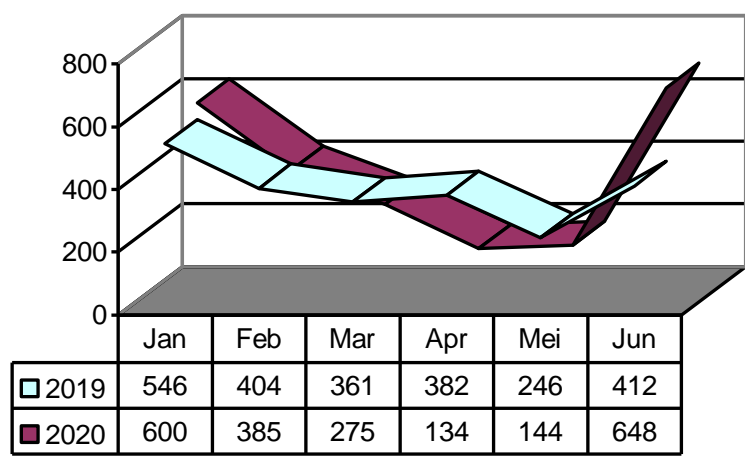

Gambar 1 Jumlah perceraian Januari hingga Juni tahun 2019 dan 2020 di Kabupaten Banyumas 
Suatu kehidupan rumah tangga harus ada kesadaran untuk saling memahami, menghormati, menghargai, dan menjaga keharmonisan. Semakin dirugikannya seseorang dalam kehidupan rumah tangganya, maka akan semakin besar potensi untuk bercerai. Teori Exchange George Homans (2004) menjelaskan semakin bernilai dan bermakna tingkah laku seseorang yang ditujukan kepada pasangannya, maka akan semakin besar kemungkinan tingkah laku tersebut diulangi. Dalam rumah tangga, ketika istri menunjukkan kasih sayang, kebaikan, dan perhatian kepada suami dan direspon dengan baik, misal membelikan barang-barang kesukaan istrinya, maka tingkah laku tersebut akan diulang terus oleh istri. Namun, bila ganjaran yang diberikan monoton dan tidak bervariasi maka akan berkurang nilai dari tingkah laku tersebut. Merujuk pada hukum Gossen II, semakin sering seseorang menerima ganjaran akan tindakan dari orang lain, semakin berkurang nilai dari setiap tindakan yang dilakukan berikutnya. Dalam kehidupan rumah tangga, idealnya masing-masing pasangan memiliki kepekaan dan memahami kesukaan masing-masing agar tidak terjadi kejenuhan dan berkurangnya nilai yang diberikan. Dampaknya menurut Teori Exchange Homans (2004), semakin dirugikan seseorang dalam hubungannya dengan orang lain maka semakin besar kemungkinan orang tersebut akan mengembangkan emosi negatif misalnya marah.

Untuk menyikapi peningkatan kasus perceraian, pemerintah telah melakukan berbagai upaya preventif. Upaya pertama dilakukan dengan cara pembatasan usia perkawinan, batasan bagi laki-laki dan perempuan di atas 19 tahun. Lebih lanjut, Badan Kependudukan dan Keluarga Berencana Nasional (BKKBN, 2013) sebagai lembaga pemerintah yang fokus pada persoalan kependudukan baik secara kuantitas maupun kualitas memiliki batasan sendiri dalam hal pernikahan yakni 21 tahun bagi perempuan dan 25 tahun bagi laki-laki. Pertimbangan 21 tahun bagi perempuan karena organ-organ reproduksi perempuan di atas usia 20 tahun sudah matang dan siap untuk dibuahi sehingga cocok untuk menikah. Pertimbangan lainnya pada usia tersebut para pasangan diharapkan sudah memiliki pendapatan sehingga sudah siap dari sisi ekonomi.

BKKBN juga memiliki program yang ditujukan bagi para remaja agar memiliki perencanaan yang matang sebelum menikah sehingga terhindari dari perceraian. Program tersebut dinamakan program GenRe (Generasi Berencana). Program ini menyasar tidak hanya remaja namun orang tua yang memiliki remaja. Program ini diimplementasikan dalam sebuah wadah yang dinamakan Pusat Informasi dan Konseling Remaja/Mahasiswa (PIK R/M). PIK R/M menurut BKKBN (2013) merupakan sebuah wadah kegiatan program KKB (Kependudukan dan Keluarga Berencana) dan PK (Pembangunan Keluarga) yang dikelola dari, oleh, dan untuk remaja guna memberikan pelayanan informasi dan konseling tentang kependudukan, keluarga berencana dan pembangunan keluarga yang didalamnya juga terkait pendewasaan usia perkawinan, delapan fungsi keluarga, Triad KRR (Kesehatan Reproduksi Remaja), keterampilan hidup, gender serta keterampilan advokasi, serta KIE (Komunikasi, Informasi dan Edukasi).

Kehadiran PIK-R di lingkungan remaja menjadi teramat penting dalam membantu mereka memperoleh informasi dan pelayanan konseling sebagai upaya penyiapan kehidupan berkeluarga yang akan datang sehingga diharapkan dapat menghindari terjadinya perceraian. Selain PIK-R, program lain yang diperuntukan bagi keluarga dengan anak remaja yaitu BKR (Bina Keluarga Remaja). BKR merupakan wadah untuk memberikan pengetahuan dan pembinaan bagi keluargakeluarga yang memiliki remaja agar mampu mengasuh, membina, dan mengarahkan para remaja menjadi remaja yang berkualitas. Begitu pula dalam hal pernikahan, melalui BKR para orang tua mampu membina remajanya untuk tidak menikah muda dan mempersiapkan semuanya sebelum menikah sehingga menjadi tindakan preventif untuk menghindari perceraian. Upaya selanjutnya yang dilakukan pemerintah ialah adanya konseling pranikah bagi para calon pengantin. Melalui program konseling, para pasangan bisa mengonsultasikan diri baik dari sisi kesehatan, finansial, psikologis dan lain-lain sehingga mereka dapat saling memahami calon pasangan masing-masing.

Pada masa pandemi Covid-19, pemerintah juga telah berupaya untuk meningkatkan ketahanan keluarga. Perwujudannya melalui Penyuluh Keluarga Berencana (PKB) yang dekat dengan masyarakat dalam melakukan strategi $3 \mathrm{P}$ (Pengorganisasian, Penguatan, Penggerakan). Pertama, pengorganisasian IMP (Institusi Masyarakat Pedesaan) baik PPKBD (Petugas Pembantu Keluarga Berencana Desa), Sub PPKBD maupun Kader KB RT agar keberadaan mereka dapat dijadikan kanal saluran komunikasi yang efektif kepada 
masyarakat luas (BKKBN, 2020). Di tengah protokol jaga jarak (social distancing), maka pengorganisasian dapat dilakukan secara daring/online dengan menggunakan aplikasi chat (WhatsApp). Semua kader IMP sampai level yang paling bawah yaitu Kader KB RT tergabung ke dalam WAG (WhatsApp Group) yang dibentuk PKB (BKKBN, 2020). Kedua, penguatan PKB untuk menciptakan kondisi siap dan percaya diri serta menjadi penghubung komunikasi ke masyarakat (BKKBN, 2020). Selanjutnya, bisa dilakukan penggerakan kader IMP dengan tujuan menggerakan kader untuk menyosialisasikan kepada masyarakat sehingga di masa pandemi Covid-19 para keluarga tetap dapat mempertahankan ketahanan keluarganya jauh dari perceraian.

Penambahan jumlah kasus perceraian terutama di masa Pandemi Covid-19 mengindikasikan bahwa kajian menyenai faktor-faktor yang menyebabkan perceraian penting untuk dilakukan. Kajian tersebut diharapkan dapat membantu untuk menemukan solusi yang tepat dalam mencegah terjadinya perceraian. Penelitian tentang faktor yang melatarbelakangi perceraian bukan hal yang baru. Hasil penelitian Nasir (2012) menyatakan tingkat pendidikan, jenis pekerjaan, tingkat ekonomi, krisis moral, kekerasan dalam rumah tangga, dan kawin paksa menjadi penyebab terjadinya perceraian. Bainah (2013) menjelaskan bahwa faktor yang menyebabkan perceraian antara lain faktor pendidikan, usia, ekonomi dan Kekerasan Dalam Rumah Tangga (KDRT).

Selanjutnya, Graff dan Kalmijn (2006) mengungkapkan masalah hubungan, perilaku, pekerjaan, dan faktor pembagian kerja merupakan faktor yang mendorong pasangan bercerai. Abdurrahman (2008) meneliti faktor agama, budaya, pendidikan, dan ekonomi sebagai faktor pencetus perceraian. Hasil penelitian di Amerika Utara dan Eropa Barat juga menunjukkan hasil yang sama bahwa penyebab langsung perceraian dapat beranekaragam seperti karakteristik psikologis pribadi dari salah satu atau kedua pasangan hingga tekanan kesulitan ekonomi dan perpecahan (Coontz, 2007). Berdasarkan hasil penelitian tersebut, faktor ekonomi merupakan faktor yang secara umum menjadi latar belakang perceraian.

Penelitian dengan tema perceraian secara umum merupakan penelitian primer bersumber dari pengumpulan data di lapangan. Penelitian dengan menganalisis data yang sudah ada pada suatu instansi masih jarang dilakukan.
Oleh karena itu, peneliti memanfaatkan data terbaru dari Pengadilan Agama Kabupaten Banyumas sebagai bahan penelitian untuk mengungkapkan perceraian di Kabupaten Banyumas. Berdasarkan pemaparan tersebut, penelitian ini bertujuan untuk mengidentifikasi karakteristik dan faktor-faktor yang melatarbelakangi perceraian selama masa pandemi Covid-19 di Kabupaten Banyumas.

\section{METODE}

Penelitian ini menggunakan metode analisis data sekunder. Pendekatan penelitian secara kuantitatif dengan desain cross-sectional study. Lokasi penelitian di Kabupaten Banyumas dengan objek penelitian berupa data perceraian yang terjadi dari bulan Maret hingga Juni 2020. Populasi dalam penelitian ini sebanyak 563 putusan perkara perceraian. Teknik penentuan sampel menggunakan simple random sampling. Untuk menentukan besarnya sampel yang diambil, peneliti menggunakan rumus Slovin dan diperoleh nilai sebesar 85 . Hal ini menandakan bahwa jumlah sampel minimal yang harus digunakan sebanyak 85 responden. Adapun jumlah responden real yang digunakan dalam penelitian ini, total 200 responden yang terdiri atas 100 istri dan 100 suami.

Pengumpulan data dilakukan dengan dokumentasi dan studi pustaka. Dokumen yang digunakan merupakan dokumen putusan Mahkamah Agung tahun 2020 pada menu statistik perkara dan menu perdata gugatan. Statistik perkara untuk melihat jumlah perceraian yang didaftarkan kemudian menu perdata gugatan memilah perkara perceraian. Untuk mendapatkan data karakteristik pelaku perceraian dan faktor-faktor yang melatarbelakanginya diambil pada dokumen putusan Mahkamah Agung 2020.

Secara umum, penelitian ini memiliki dua variabel yang menjadi fokus penelitian yaitu karakteristik demografi dan faktor penyebab perceraian. Karakteristik demografi adalah ciri yang menggambarkan perbedaan masyarakat berdasarkan usia, jenis kelamin, pekerjaan, pendidikan, agama, suku bangsa, pendapatan, jenis keluarga, status pernikahan, lokasi geografi, dan kelas sosial (Kotler \& Armstrong, 2001). Karakteristik demografi terdiri atas usia istri, usia suami, pendidikan istri, pendidikan suami, pekerjaan istri, pekerjaan suami, lama menikah, dan jumlah anak. Faktor penyebab perceraian merupakan faktor yang menyebabkan berakhirnya masa perkawinan dan telah diputuskan oleh pengadilan agama. 
karakteristik demografi terdiri atas usia istri, usia suami, pendidikan istri, pendidikan suami, pekerjaan istri, pekerjaan suami, lama menikah, dan jumlah anak. Usia merupakan waktu lamanya hidup atau ada (sejak dilahirkan atau diadakan) (Hoetomo, 2005). Penentuan usia responden didapatkan dari dokumen putusan perceraian yang dikeluarkan Mahkamah Agung. Untuk mempermudah analisis usia, maka dilakukan kategori usia dengan interval lima tahun, yaitu 15-19 tahun, 20-24 tahun, 25-29 tahun dan seterusnya. Menurut demografi distribusi umur penduduk dapat digolongkan menurut umur satu tahunan maupun lima tahunan (Nurdin, 2004). Lama menikah yaitu durasi waktu pasangan menjadi suami istri. Lama menikah dikategorikan menjadi empat interval, yaitu $<5$ tahun, 6-10 tahun, 11-15 tahun, dan >15 tahun. Pengkategorian ini berdasarkan pada hasil penelitian Nasir (2012) bahwa perceraian terjadi pada rentang usia pernikahan yang masih muda yaitu 0-5 tahun. Didukung penelitian Rahmaita, Pranaji, dan Yuliati (2016), semakin lama pernikahan maka kepuasan perkawinan juga semakin meningkat atau baik sehingga ketahanan keluarga semakin kuat. Jumlah anak merupakan jumlah anak hidup yang dimiliki pasangan suami istri selama masih bersatus suami istri. Faktor penyebab perceraian diklasifikasikan menjadi dua yaitu faktor suami dan faktor istri.

Tahapan yang harus dilakukan oleh peneliti untuk melakukan analisi data yaitu coding, entering, cleaning, dan output (Faisal, 2001; Neuman, 2003). Analisis data dimulai dari mengkoding data dengan cara menyusun data dari dokumen Mahkamah Agung yang berbentuk surat keputusan menjadi bentuk yang mudah dibaca oleh mesin pengolah data. Langkah selanjutnya dilakukan data entering, yakni memindahkan data yang sudah diubah dalam kode angka ke dalam laptop dan selanjutnya diolah menggunakan program Statistical Package for Social Science (SPSS). Lebih lanjut, dilakukan data cleaning dengan cara mengecek untuk memastikan seluruh data telah dimasukkan ke dalam laptop dan sesuai dengan informasi yang sebenarnya tertuang dalam dokumen Mahkamah Agung. Langkah terakhir data output menggunakan distribusi frekuensi dengan nilai modus untuk menentukan kecenderungan data. Selanjutnya, data disajikan menggunakan grafik, tabel, dan diagram.

\section{HASIL}

\section{Penggugat Perceraian}

Penggugat perceraian secara umum berasal dari istri dengan persentase 69 persen, sisanya berasal dari suami dengan persentase 31 persen. Hal ini mengindikasikan bahwa istri merupakan pihak yang tidak mendapatkan imbalan atas harapan dari perkawinan yang dibinanya. Imbalan untuk mendapatkan kebahagiaan saat membangun rumah tangga tidak dirasakan oleh istri. Hal tersebut menyebabkan ikatan rumah tangga renggang sehingga memutuskan untuk bercerai dan menjadi single parent. Pilihan untuk menjadi wanita mandiri dirasa mampu ditangani oleh para istri.

\section{Karakteristik Demografi Pelaku Perceraian}

Pelaku perceraian pada penelitian ini merujuk pada kedua belah pihak yang bercerai yaitu suami dan istri. Variabel-variabel yang merepresentasikan karakteristik demografi terdiri atas usia istri, usia suami, pendidikan istri, pendidikan suami, pekerjaan istri, pekerjaan suami, lama menikah, dan jumlah anak.

Usia. Para pelaku perceraian berada pada rentang usia yang cukup muda. Hampir setengah istri dari total jumlah responden berusia 21-30 tahun dan mayoritas suami memiliki rentang usia 31-40 tahun. Lebih Ianjut, disusul usia 31-40 tahun pada istri sebanyak 31 persen dan suami yang berusia 21-30 tahun sebanyak 34 persen serta kelompok usia 41-50 tahun masing-masing 17 persen. Untuk kategori usia yang paling muda ( $<21$ tahun), tidak ada suami yang berada pada rentang usia ini, namun 7 persen istri terkategori berada pada rentang usia paling muda. Sedangkan pada kelompok usia tua di atas 60 tahun pada suami lebih besar dua kali dibandingkan istri yakni 4 persen suami dan istri 2 persen.

Pendidikan. Pada penelitian ini tingkat pendidikan diklasifikasikan menjadi tamat Sekolah Dasar (SD), Sekolah Menengah Pertama (SMP), Sekolah Menengah Atas (SMA), Diploma, dan Strata Satu (S1). Sebaran responden berdasarkan tingkat pendidikan pelaku perceraian disajikan pada Gambar 2. Persentase tertinggi tingkat pendidikan perempuan (istri) berada pada jenjang SMP, sedangkan persentase tertinggi tingkat pendidikan laki-laki (suami) berada pada jenjang SD. Jika dilihat berdasarkan jenjang perguruan tinggi (Diploma dan S1), jumlah perempuan (istri) yang menyelesaikan Pendidikan pada jenjang perguruan tinggi lebih banyak dari pada jumlah laki-laki (suami). 


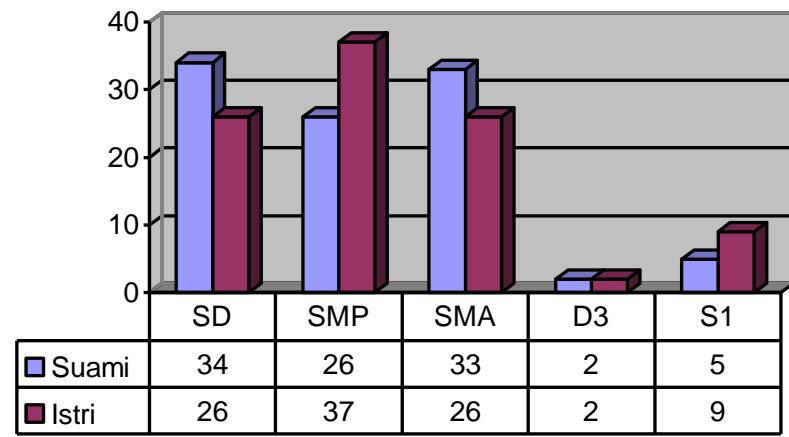

Gambar 2 Sebaran responden berdasarkan tingkat pendidikan pelaku perceraian

Pekerjaan. Perempuan pelaku perceraian tidak memiliki pekerjaan yang menghasilkan pendapatan. Hal ini disebabkan karena mayoritas istri (38\%) mengurus rumah tangga. Lebih lanjut, mayoritas suami (35\%) bekerja sebagai buruh (Gambar 3). Keterbatasan data untuk jenis pekerjaan menjadikan tidak mampu menyampaikan data pekerjaan semua pelaku perceraian. Ada 19 persen pada perempuan tidak menyebutkan pekerjaan dan 31 persen laki-laki. Kemungkinan data tersebut bersifat privat bagi sebagian pelaku perceraian.

Usia Perkawinan. Karakteristik responden berdasarkan lama usia perkawinan yaitu sebagian besar kasus perceraian terjadi pada usia perkawinan yang masih muda (kurang dari 5 tahun) sebanyak 44 persen. Selanjutnya pada rentang usia perkawinan 6-10 tahun sejumlah 38 persen. Lebih lanjut, hasil yang menarik dalam penelitian ini yaitu lamanya pernikahan ternyata tidak menjamin keutuhan perkawinan karena ada 11 persen yang menikah lebih dari 15 tahun tetapi perceraian tetap terjadi diantara pasangan suami-istri tersebut (Gambar 4).

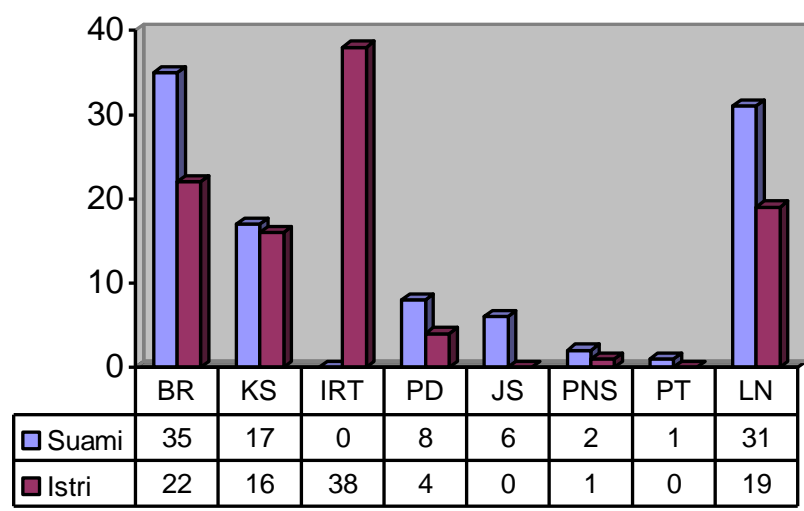

Keterangan: $\mathrm{BR}=$ buruh; $\mathrm{KS}=$ karyawan swasta; IRT=ibu rumah tangga; $\mathrm{PD}=$ pedagang; $\mathrm{JA}=$ jasa; $\mathrm{PN}=\mathrm{PNS}$; $\mathrm{PT}=$ petani; $\mathrm{LN}=$ lainnya

Gambar 3 Sebaran responden berdasarkan jenis pekerjaan pelaku perceraian

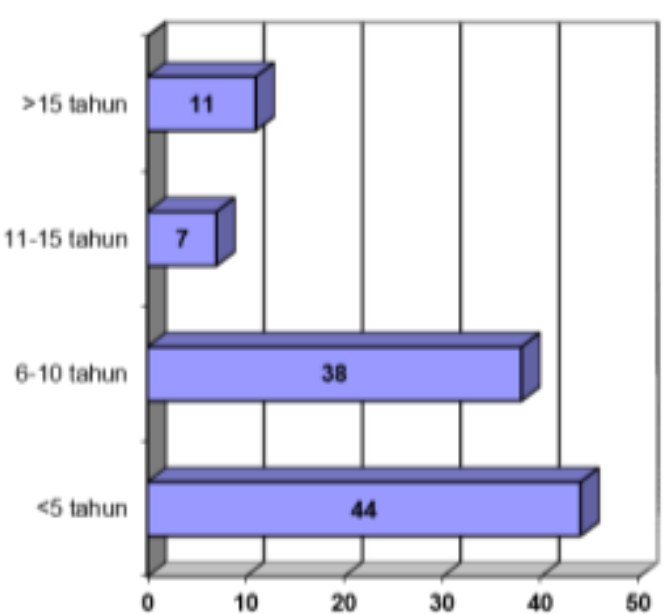

Gambar 4 Sebaran responden berdasarkan lama usia pernikahan

Jumlah Anak. Untuk jumlah anak secara umum pasangan yang melakukan perceraian baru memiliki satu anak sebanyak 48 persen bahkan ada yang belum memiliki anak sebanyak 28 persen. Kemudian memiliki 2 anak sebanyak 18 persen, 3 anak ada sebanyak 5 persen dan terakhir memiliki 4 anak sebanyak 1 persen. Jumlah anak yang dimiliki oleh pasangan cukup bervariasi dari yang hanya satu anak sampai 4 anak bahkan ada yang belum mempunyai anak. Semuanya memutuskan untuk melakukan perceraian. Artinya, keberadaan anak tidak menjadi faktor dasar pertimbangan bagi pasangan untuk bercerai.

\section{Alasan Perceraian}

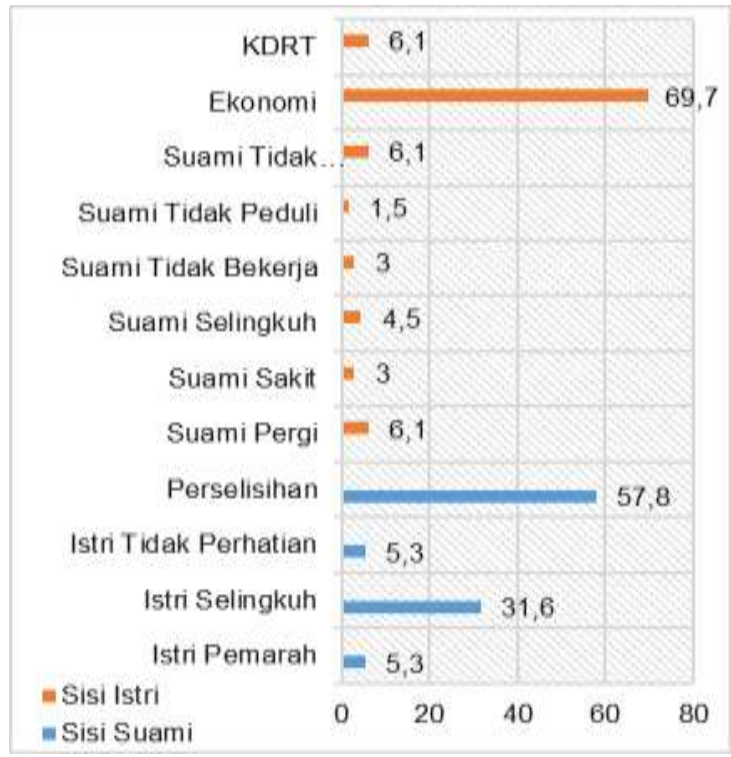

Gambar 5 Persentase responden berdasarkan alasan perceraian 
Secara keseluruhan ada 12 aspek yang menjadi alasan perceraian. Mayoritas istri $(69,7 \%)$ mengungkapkan bahwa alasan utama yang melatarbelakangi terjadinya perceraian yaitu faktor ekonomi. Suami tidak mampu untuk memenuhi seluruh kebutuhan dasar keluarga dikarenakan jumlah pendapatan yang tidak muncukupi. Selain dari sisi istri, alasan utama suami $(57,8 \%)$ saat memutuskan untuk berpisah dikarenakan timbulnya perselisihan di antara kedua belah pihak yang berlarut-larut. Perselisihan tersebut muncul karena adanya perbedaan dalam memilih tempat tinggal. kedua belah pihak tidak mau tinggal bersama di salah satu orang tua baik laki-laki maupun perempuan. Akhirnya tidak ditemukan titik temu sehingga keduanya memiliki pertimbangan masing-masing yang tidak mau dikalahkan. Secara umum, para pelaku perceraian belum memiliki tempat tinggal sendiri dan masih banyak yang tinggal bersama kedua orang tuanya. Lebih lanjut, hasil analisis mengungkapkan bahwa faktor selingkuh lebih banyak dilakukan istri $(31,6 \%)$ dibandingkan suami $(4,5 \%)$. Istri yang selingkuh umumnya ditemui pada suami-suami yang bekerja jauh (buruh di luar negeri, karyawan swasta, pegawai BUMN). KDRT yang dilakukan oleh suami juga menjadi faktor mengajukan gugatan perceraian. KDRT dilakukan oleh para suami yang memiliki kebiasaan mabuk-mabukan sehingga berdampak pada emosi tak terkendali $(6,1 \%)$ (Gambar 5).

\section{PEMBAHASAN}

Perceraian merupakan peristiwa kehidupan dengan tingkat stres yang tinggi bagi seluruh keluarga (Spremo, 2020). Bahkan penelitian Sbarra (2015) menyatakan, pengalaman perpisahan atau perceraian memberikan risiko kesehatan yang buruk dan tingkat kematian. Untuk itu, tidak ada orang yang mengharapkan perceraian dalam pernikahan yang dibangun. Mereka mendambakan keluarga yang bahagia sampai kakek nenek bahkan sampai ajal. Namun pada perjalanannya ada yang tidak sempurna. Berbagai persoalan muncul dalam kehidupan rumah tangga. Ada yang mampu mengatasi persoalan tersebut dan ada juga yang tidak mampu. Bagi keluarga yang mampu menyelesaikan masalah dalam keluarga akan semakin memperkuat ketahanan keluarga, sedangkan bagi keluarga yang tidak mampu, persoalan yang terjadi dalam keluarga akan menghancurkan kehidupan keluarga tersebut.

Ketahanan keluarga bersifat dinamis dan dapat dipengaruhi oleh faktor eksternal. Di saat pandemi Covid-19, keluarga mengalami dinamikan kehidupan. Penelitian Prime, Wade, dan Browne (2020) menyatakan bahwa pandemi Covid-19 merupakan ancaman akut bagi kesejahteraan anak-anak dan keluarga karena terkait dengan gangguan sosial seperti ketidakstabilan finansial, beban pengasuhan, dan stres. Penelitian di Australia mengungkapkan, Covid-19 berdampak pada ketidakpastian, kesepian, kekhawatiran finansial, tingkat depresi, kecemasan dan stres, bahkan satu dari empat individu melaporkan peningkatan kecemasan kesehatan dalam seminggu terakhir (Newby, O'Moore, Tang, Christensen, \& Faasse, 2020). Pada situasi tersebut keluarga mengalami goncangan, yang disebabkan oleh ketidakmampuan menerima kenyataan serta tidak memiliki persiapan. Akhirnya, ketahanan keluarga pun goyah, masing-masing pasangan tidak mau menjadi bagian yang tertindas maupun menindas. Ada kekecewaan, ada yang dirugikan dan tidak menerimanya. Pilihan berpisah menjadi kesepakatan bersama menyelesaikan konflik yang terjadi.

Hasil penelitian menunjukkan bahwa pelaku perceraian masih berusia muda. Hampir setengah istri dari total jumlah responden berusia 21-30 tahun dan mayoritas suami memiliki rentang usia 31-40 tahun. Hal ini sesuai dengan kajian sebelumnya yang mengungkapkan bahwa sebagian pasangan yang bercerai menikah pada usia muda. Rentan usia tersebut merupakan usia produktif dalam bekerja dan mengembangkan karier. Selain itu, menurut Karim (2004), pada usia muda seseorang masih dalam proses pembentukan kepribadian, kondisi ekonomi yang masih labil dan kondisi keuangan yang belum mapan, sedangkan dalam perkawinan harus saling berbagi dengan pasangan. Ketidakmampuan berbagi dan memahami pasangan bisa mengarah pada perceraian.

Selain usia, tingkat pendidikan juga dapat menjadi salah satu faktor penyebab perceraian. Persentase tertinggi tingkat pendidikan perempuan (istri) berada pada jenjang SMP, sedangkan persentase tertinggi tingkat pendidikan perempuan (suami) berada pada jenjang SD. Pendidikan memengaruhi seseorang mengambil keputusan dalam menghadapi persoalan. Pendidikan berhubungan dengan pola pikir, persepsi dan perilaku masyarakat secara signifikan, dalam arti semakin tinggi tingkat pendidikan seseorang semakin rasional dalam pengambilan berbagai keputusan (Lontaan \& Kusmiyati, 2014). Sejalan dengan hal tersebut menurut UNESCO pendidikan itu identik dengan belajar. 
Pendidikan menurut UNESCO diartikan sebagai learning to think (belajar berpikir), learning to do (belajar melakukan), learning to be (belajar menjadi), dan learning to live together (belajar dengan berkerjasama) (Yatimah, 2017).

Mayoritas penggugat perceraian dalam penelitian ini adalah istri. Sebagian besar istri yang menjadi penggugat perceraian merupakan ibu rumah tangga yang tidak bekerja di sektor publik. Kondisi ini memperlihatkan bahwa istri berada pada posisi yang belum merdeka secara finansial dan masih bergantung kepada suami. Ketika memutuskan berpisah maka istri harus berusaha sendiri untuk memenuhi kebutuhan hidupnya. Perceraian akan berdampak pada kehidupan istri. Salah satu dampak yang ditimbulkan adalah kecemasan. Faktor penyebab kecemasan pada perempuan yang bercerai dikarenakan ketidaksiapan seorang ibu rumah tangga untuk bekerja di sektor publik (Pragholapati, 2020). Para ibu rumah tangga didorong untuk mencari pekerjaan yang sesuai dengan pendidikannya demi memenuhi kebutuhan hidup. Namun, disaat upaya mencari pekerjaan mengalami hambatan, maka akan muncul kecemasan berkali-kali lipat dari sebelumnya. Hal ini didukung oleh hasil penelitian Pinel (2012) yang mengungkapkan bahwa perempuan memiliki kecemasan dua kali lebih tinggi dari laki-laki. Gangguan kecemasan merupakan gangguan yang paling menonjol di antara semua gangguan psikologis (Pragholapati, 2020).

Penelitian ini mengidentifikasi bahwa kasus perceraian terjadi pada usia perkawinan kurang dari 5 tahun. Secara nasional juga menunjukan hal yang sama sebanyak 80 persen perceraian terjadi pada perkawinan di bawah usia lima tahun (Republika, 2013). Hal ini sejalan dengan penelitian Karim (2004) yang menjelaskan bahwa perceraian paling banyak terjadi pada kelompok usia perkawinan lima tahun kebawah. Usia perkawinan kurang dari lima tahun merupakan tahap awal dalam membina rumah tangga sehingga masih banyak perselisihan dan perbedaan yang terjadi. Kedua pasangan masih dalam tahap beradaptasi. Masingmasing memiliki ego dan ketika tidak mampu menyesuaikan diri maka yang akan terjadi adalah perpecahan. Oleh karena itu, diperlukan komunikasi dan komitmen yang kuat untuk saling memahami pasangannya sehingga muncul sikap saling pengertian dan perhatian dan akan mempermudah proses adaptasi.

Jumlah anak yang dimiliki tidak menjadi pertimbangan dalam memutuskan untuk bercerai. Asalkan keduanya bisa tetap menjalankan perannya sebagai ayah maupun sebagai ibu. Pertimbangan ketika keluarga sudah memiliki anak, maka kebutuhan keluarga semakin bertambah, namun pertambahan pengeluaran ini tidak diimbangi dengan pendapatan. Jika suami bersikap tidak peduli dalam pemenuhan kebutuhan hidup keluarga terutama anaknya maka akan memicu ketidakharmonisan dan rentan akan perceraian. Selain itu, pertimbangan psikologis anak sepertinya tidak menjadi menjadi dasar pertimbangan untuk mengakhiri sebuah pernikahan. Padahal, perceraian orang tua berdampak buruk pada konsisi psikologis anak.

Secara psikologis anak yang kedua orang tuanya bercerai mengalami risiko terhadap tumbuh kembang jiwanya (Ramadhani \& Hetty, 2019). Bahkan hingga saat ini perceraian orang tua dapat memberikan dampak buruk terhadap fisik dan psikologis anak (Ramadhani \& Hetty, 2019). Anak yang biasa mendapatkan kedua orang tuanya utuh harus menerima kenyataan semuanya sudah berubah. Mereka sudah tidak bisa bersama-sama untuk berbagi cerita, saling mengantar ke sekolah, dan makan bersama. Individu yang berpisah dan bercerai memiliki risiko yang lebih tinggi mengalami penyakit fisik dan mental dibandingkan dengan pasangan yang masih menikah (Kiecolt-Glaser, 2018). Anak dari keluarga bercerai memiliki skor yang lebih rendah dalam berbagai macam perkembangan yang meliputi prestasi akademik, penyesuaian psikologis, konsep diri dan keterampilan sosial (Asilah \& Hastuti, 2013). Oleh karena itu orang tua harus lebih besar untuk membantunya mengatasi kehilangan yang dialami selama masa sulit setelah orang tuanya bercerai (Ningrum, 2013). Namun ada pasangan yang telah berpisah lalai akan hal itu. Mereka sibuk menyiapkan kehidupannya masing-masing. Anak menjadi korban yang paling parah. Keberadaan anak dalam keluarga yang retak juga tidak baik, banyak anak-anak yang terjerumus pada tindakan negatif karena berada pada lingkungan keluarga yang tidak menguntungkan. Pertengkaran dan perselisihan yang diperlihatkan kedua orang tuanya hanya akan membuat suasana rumah tidak nyaman dan anak semakin tertekan. Pada keadaan seperti ini, anak biasanya lebih memilih menyendiri dengan tinggal di rumah kakek maupun neneknya. Ketiadaan anak dalam sebuah keluarga ternyata tidak berhubungan dengan keputusan bercerai. Hasil ini sejalan dengan Leslie dalam Karim (2004) belum tentu perceraian berhubungan langsung dengan ketiadaan anak dalam suatu keluarga, dengan 
kata lain adanya anak dalam suatu keluarga bukan merupakan pencegah efektif untuk terjadinya perceraian.

Hasil penelitian ini menemukan 12 variabel yang menjadi alasan terjadinya perceraian. Ekonomi menjadi alasan utama istri untuk bercerai dengan suaminya. Hasil ini menguatkan temuan BPS (2019) bahwa ekonomi merupakan faktor terbanyak kedua yang membuat istri memilih berpisah (120.732 kasus) setelah perselisihan dan pertengkaran yang terus menerus. Faktor ekonomi dapat memengaruhi hubungan sosial (Johnson, 1994). Hasil penelitian Kalmijn, Loeve, dan Manting (2007) kesetaraan pendapatan akan mengurangi risiko perceraian bagi pasangan suami istri. Terkait dengan pandemi Covid-19, banyak suami-suami yang tidak bekerja lagi. Dampaknya, keuangan menjadi tidak stabil bahkan tidak cukup dalam memenuhi kebutuhan keluarga sehingga banyak istri yang menggugat suaminya karena alasan ekonomi. Hal ini sejalan dengan penelitian Wongkaren (2000) bahwa perceraian dapat disebabkan faktor keuangan. Penelitian Lestari (2012) menyatakan, persoalan ekonomi sering menjadi salah satu pemicu utama perceraian. Kebahagiaan keluarga dipengaruhi faktor ekonomi, ketika kebutuhan keluarga mampu terpenuhi maka seluruh anggota keluarga mampu hidup dengan damai dan bahagia.

Suami tidak bekerja, pergi, tidak peduli dan tidak tanggung jawab. Keempat alasan perceraian ini saling berhubungan. Suami tidak tanggung jawab terkait dengan persoalan ekonomi karena banyak istri menggungat cerai dengan alasan suami tidak mau bekerja sehingga tidak bertanggung jawab dalam memberikan nafkah bagi keluarga. Begitu pula suami pergi meninggalkan keluarga dan tidak peduli. Idealnya masing-masing menjalankan kewajiban. Suami menjaga istri dan menyediakan kebutuhan hidup layak bagi keluarga. Istri menjaga atau mengatur rumah tangga apapun yang menimpa keluarga merupakan masalah yang harus ditanggung dan diselesaikan bersama (Harjianto, 2019).

KDRT menjadi alasan adanya perceraian yang diajukan istri. Adanya masa karantina membuat angka kekerasan dalam rumah tangga terhadap perempuan serta anak meningkat secara global. Hal ini terjadi karena banyaknya suami yang mengalami penurunan pendapatan hingga kehilangan pekerjaan namun kebutuhan dasar kelurga yang tinggi harus tetap terpenuhi. Tingginya tekanan yang dirasakan membuat suami melampiaskan rasa stres dan emosi serta frustrasi pada anak dan istri (Radhitya, Nurwati, \& Irfan, 2020). Bahkan di Brasil, Spanyol, Siprus, Inggris dan Australia, selama pandemi Covid-19 ada peningkatan laporan kekerasan dalam rumah tangga sebesar 11 persen (Neil, 2020).

Alasan utama lain yang memicu terjadinya perceraian yaitu perselingkuhan yang dilakukan oleh istri dan suami. Hal ini akan bermuara pada ketidakharmonisan hubungan di antara keduanya (Ghoffar, 2006). Perselingkuhan memberikan dampak buruk pada berbagai aspek kehidupan seluruh anggota keluarga, diantaranya yaitu hancurnya masa depan anakanak, rasa malu yang ditanggung keluarga besar, rusaknya karier, serta merusak tatanan sosial di masa mendatang (Fajri \& Mulyono, 2017). Menurut Surya (2009), perselingkuhan umumnya terjadi pada anggota keluarga yang kurang memiliki kualitas keagamaan, lemahnya dasar cinta, sikap egois, komunikasi kurang lancar dan harmonis, emosi kurang stabil, dan kurang mampu membuat penyesuaian diri. Selain itu, suami sakit juga menjadi alasan istri menggugat cerai. Bentuk sakit dapat berupa sakit jiwa yang parah dan susah disembuhkan sehingga membuat suami tidak mampu menjalankan kewajibannya (Hermady, 2004).

Faktor perselisihan menunjukkan perbedaan pendapat yang memicu konflik rumah tangga. Menurut Suhendi dan Wahyu (2001), konflik yang timbul dalam perkawinan bukan karena perbedaan antara suami istri, melainkan karena suami istri tidak mampu hidup ditengah-tengah perbedaan yang ada di antara mereka, dan perceraian dapat dipahami sebagai kegagalan suami istri dalam menegosiasi penyelesaian konflik yang terjadi.

Istri tidak perhatian menjadi salah satu faktor suami memilih berpisah. Hal ini karena istri sibuk dengan kegiatan. Contohnya arisan, aktivitas ini terkadang melebihi batas kewajaran sehingga melupakan kewajiban sebagai ibu rumah tangga (Abdullah, 2016; Matondang, 2014).

Istri pemarah mengakibatkan suami memilih berpisah. Mungkin karena menumpuknya pekerjaan rumah tangga tanpa diimbangi kasih sayang suami. Pekerjaan rumah tangga yang menyita banyak waktu dan tenaga membuat istri merasa terisolasi dan berpotensi menimbulkan stres (Putri \& Sudhana, 2013).

Alasan perceraian memperlihatkan perkawinan yang dilakukan tidak memenuhi harapan. Harapan akan keluarga yang bahagia dengan 
terpenuhinya kebutuhan baik kebutuhan psikologis dan kebutuhan ekonomi, namun yang terjadi sebaliknya. Kondisi in tentunya tidak menguntungkan dan jalan terbaiknya berpisah. Serupa dengan Teori Exchange Ritzer (2004), seseorang yang merasa dirugikan dalam suatu hubungan cenderung akan meluapkan emosinya dengan marah. Marah menjadi bagian awal dari ketidakpuasan yang dialami. Karena berlarut-larut dan tidak menemukan titik temu maka berpisah menjadi langkah menyelesaikan ketidakadilan dalam hubungan rumah tangga.

Komunikasi bisa menjadi jembatan mengurangi perselisihan yang terjadi. Melalui komunikasi, dapat tersampaikan pikiran atau perasaan kepada orang yang dituju. Komunikasi berlaku apabila komunikator bermaksud memberitahukan sesuatu kepada orang lain (Sopacua, 2011). Lasswell (1960) mengungkapkan, cara terbaik saat akan melakukan proses komunikasi yaitu dengan memahami sumber pesan, isi, dan media/saluran. Terkadang komunikasi tidak berjalan baik dan mengalami kendala karena tidak memiliki saluran untuk menyampaikanya. Begitu pula dalam keluarga, ketika saling bersilang pendapat dan tidak ada jalan keluar, perlu mediator untuk menyampaikan pesan dari kedua pihak. Cepat atau lambatnya penyelesaian suatu masalah tergantung pada kemampuan mediator merespons dan menemukan titik penyelesaian sehingga terjadi interaksi. Menurut Ritzer (2004) kemampuan proses interaksi yang harmonis dan komunikasi yang baik antara suami istri meminimalisir konflik dan perceraian.

Strategi pencegahan dan penanggulangan perceraian tidak hanya tanggung jawab pemerintah. Hal ini disebabkan karena perceraian bersifat multidimensional sehingga aspek sosial, kultural, dan moral, serta semua unsur potensi dan pranata sosial dalam komunitas lokal juga berperan dalam menanggulangi bahkan mencegah terjadinya perceraian (Fachrina \& Putra, 2013). Keluarga menjadi pendekatan yang merangkul calon suami istri memberikan pendidikan tentang keluarga. Sebab keluarga memiliki delapan fungsi, meliputi fungsi agama, sosial budaya, cinta kasih, perlindungan, reproduksi, sosialisasi dan pendidikan, ekonomi, dan lingkungan. (BKKBN, 2013). Fungsi agama mengajarkan cara beribadah sesuai agamanya. Fungsi sosial mengajarkan nilai-nilai luhur budaya bangsa yang harus dilestarikan. Fungsi cinta kasih mengajarkan saling mengasihi antar anggota keluarga. Fungsi perlindungan melindungi dari ancaman fisik maupun psikis. Fungsi reproduksi mengajarkan menjaga kesehatan organ reproduksi untuk melahirkan keturunan sehat. Fungsi sosialisasi dan pendidikan, memberikan pendidikan tingkat formal maunpun nonformal dalam mewujudkan cita-citanya. Fungsi ekonomi mengajarkan hidup hemat, suka menabung dan membeli berdasarkan kebutuhan. Fungsi lingkungan mengajarkan cara menjaga lingkungan, tidak membuang sampah sembarangan, menembang pohon secara liar sehingga lingkungan asri dan memenuhi kebutuhan manusia.

\section{SIMPULAN DAN SARAN}

Secara umum penggugat perceraian berasal dari pihak istri dengan karakteristik usia muda, berpendidikan rendah, tidak bekerja, usia perkawinan kurang dari lima tahun dan baru memiliki satu anak. Alasan mengajukan perceraian karena faktor ekonomi. Oleh karena itu bagi Badan Kependudukan dan Keluarga Berencana (BKKBN) provinsi Jawa Tengah dan OPD KB (Organisasi Perangkat Daerah Keluarga Berencana) Kabupaten Banyumas perlu melakukan sosialisasi yang intens tentang penyiapan kehidupan berkeluarga bagi para calon pasangan suami istri dalam hal ekonomi, sosialisasi delapan fungsi keluarga dan pendewasaan usia perkawinan. Sosialisasi tidak hanya dilakukan oleh para Petugas Keluarga Berencana (PKB), namun melalui media-media yang menjangkau masyarakat misalnya melalui televisi dan radio lokal Banyumas. Selain itu dengan menggandeng instansi yang peduli pada keluarga misalnya Dinas Pendidikan, Kantor Urusan Agama, para akademisi dll untuk berperan serta menggalakkan kepada masyarakat.

Keterbatasan penelitian ini adalah, peneliti memanfaatkan data yang ada di pengadilan agama Banyumas dan pengadilan agama Purwokerto serta data direktori putusan Mahkamah Agung dengan tidak menambahkan pengukuran secara mendalam melalui wawancara kepada pelaku perceraian dan anak-anak pelaku perceraian sehingga data yang disajikan murni dari data yang terkumpul di pengadilan agama dan direktori putusan. Diharapkan penelitian selanjutnya dapat melakukan pengukuran lebih dalam melalui wawancara sehingga didapatkan hasil yang lebih komprehensif. Selain itu, tidak hanya mengumpulkan data karakteristik pelaku perceraian dan faktor yang melatarbelakanginya, namun sampai kepada dampak perceraian terhadap anak. 


\section{DAFTAR PUSTAKA}

Abdullah, V. A. (2016). Arisan sebagai gaya hidup (sebuah kritik terhadap masyarakat perkotaan). Jurnal Komunikasi, 11(1), 1728.

doi:https://doi.org/10.20885/komunikasi.vol 11.iss1.art2.

Abdurrahman, E. (2008). Pola perkawinan dan perceraian di Jawa Barat. Jakarta, ID: Lembaga Demografi FEUI.

Asilah, A., \& Hastuti, D. (2013). Hubungan tingkat stres ibu dan pengasuhan penerimaan penolakan dengan konsep diri remaja pada keluarga bercerai. Jurnal IImu Keluarga dan Konsumen, 7(1), 10-18. doi:https://doi.org/10.24156/jikk.2014.7.1.1 0 .

Bainah, N. (2013). Faktor-faktor penyebab perceraian di kelurahan Long Ikis Kabupaten Paser. eJournal Sosiatri Sosiologi, 1(1), 74-83.

[BKKBN \& IPB] Badan Kependudukan dan Keluarga Berencana Nasional \& Institut Pertanian Bogor. (2020). Survei Kondisi Keluarga pada Masa Pandemi Covid-19. Jakarta, ID: BKKBN \& IPB.

[BKKBN] Badan Kependudukan dan Keluarga Berencana Nasional. (2013). Program Genre dalam Penyiapan Kehidupan Berkeluarga bagi Remaja. Jakarta, ID: BKKBN.

[BKKBN] Badan Kependudukan dan Keluarga Berencana Nasional. (2020). Strategi Komunikasi Risiko di Akar Rumput. Jakarta, ID: BKKBN.

Cao, W., Fang, Z., Hou, G., Han, M., Xu, X., Dong, J., \& Zheng, J. (2020). The psychological impact of the Covid-19 epidemic on college students in China. Psychiatry Research, 287(March), 1-5. doi:https://doi.org/10.1016/j.psychres.2020 .112934 .

Chou, F. H., Su, T. T., Chou, P., Ou-Yang, W. C., Lu, M. K., \& Chien, I. C. (2005). Survey of psychiatric disorders in a Taiwanese village population six months after a major earthquake. Journal of the Formosan Medical Association = Taiwan yi zhi, 104(5), 308-317.

Cohan, C. L., \& Cole, S. W. (2002). Life course transitions and natural disaster: Marriage, birth, and divorce following Hurricane Hugo. Journal of family psychology, 16(1), 14-25. doi:https://doi.org/10.1037//08933200.16.1.14.
Coontz, S. (2007). The origins of modern divorce. Family process, 46(1), 7-16. doi:https://doi.org/10.1111/j.15455300.2006.00188.x.

Detik-News. Perceraian di Pulau Jawa meningkat gegara pandemi Covid-19. (2020). Retrieved from https://news.detik.com/berita/d-5150980/ perceraian-di-pulau-jawa-meningkat-gegar a-pandemi-covid-19.

Fachrina \& Putra, R. E. (2013). Upaya pencegahan perceraian berbasis keluarga luas dan institusi lokal dalam masyarakat Minangkabau di Sumatra Utara. Jurnal Antropologi Indonesia, 34(2), 101-111.

Faisal, S. (2001). Format-format penelitian sosial. Jakarta, ID: Rajawali Press.

Fajri, K., \& Mulyono. (2017). Selingkuh sebagai salah satu faktor penyebab perceraian. Jurnal Studi Hukum Islam, 6(1), 1-11.

Hermady, E. (2004). Gugatan perceraian di pengadilan agama dengan alasan sakit jiwa (Thesis). Surabaya, ID: Universitas Airlangga.

Homans, G. (2004). Sosial behavior: Its elementary forms. New York, US: Harcourt, Brace and word.

Ghoffar, M. A. (2006). Menyikapi tingkah laku suami. Jakarta, ID: Almahira.

Graff \& Kalmijn. (2006). Divorce motives in a period of rising divorce: Evidence from a dutch life-history survey. SAGE Journals, 27(4), 483-505. doi:https://doi.org/10.1177\%2F0192513X0 5283982.

Harjianto, R. J. (2019). Identifikasi faktor penyebab perceraian sebagai dasar konsep pendidikan. Jurnal IImiah Universitas Batanghari Jambi, 19(1), 3541. doi:https://doi.org/10.33087 /jiubj.v19i1.54.

Hoetomo. (2005). Kamus lengkap bahasa Indonesia. Jakarta, ID: Mitra Pelajar Swadaya.

Johnson, D. P. (1994). Teori sosiologi klasik dan modern jilid I. Jakarta, ID: Gramedia Pusaka Utama.

Kalmijn, M., Loeve, A., \& Manting, D. (2007). Income dynamics in couples and the dissolution of marriage and cohabitation. Demography, 44(1), 159 $179 . \quad$ doi:https://doi.org/10.1353/ dem.2007.0005. 
Karim, E. (2004). Pendekatan perceraian dari perspektif sosiologi. Jakarta, ID: Yayasan Obor Indonesia.

Kiecolt-Glaser, J. K. (2018). Marriage, divorce, and the immune system. The American psychologist, 73(9), 1098-1108. doi:https://doi.org/10.1037/amp0000388.

Kotler \& Amstrong. (2001). Prinsip-prinsip pemasaran. Jakarta, ID: Erlangga.

Lasswell, H. (1960). The structure and function of communication in society, in mass communications. A book of readings selected and edited by the Director of the Institute for Communication Research at Stanford University (Eds: Wilbur Schramm) Urbana, US: University of Illinois Press.

Lestari, S. (2012). Psikologi keluarga. Jakarta, ID: Kencana Prenada Media Grup.

Lontaan, A., \& Kusmiyati. (2014). Faktor-faktor yang berhubungan dengan pemilihan kontrasepsi pasangan usia subur di puskesmas Damau Kabupaten Talaud. Jurnal Ilmiah Bidan, 2(1), 27-32. doi:https://doi.org/10.47718/jib.v2i1.312.

Luo, M., Guo, L., Yu, M., \& Wang, H. (2020). The psychological and mental of Coronavirus Disease 2019 (Covid-19) on medical staff and general public-A systematic review and meta-analysis. Psychiatry Research, 2919(April), 113190. doi:https://doi.org/10.1016/j.psychres.2020 .113190 .

Matondang, A. (2014). Faktor-faktor yang mengakibatkan perceraian dalam perkawinan. Jurnal Ilmu Pemerintahan dan Sosial Politik, 2(2), 141-150.

Nasir, B. (2012). Faktor-faktor yang mempengaruhi perceraian di kecamatan sungai kunjang kota Samarinda. Jurnal Psikostudia Universitas Mulawarman, 1(1), 31-48. doi:http://dx.doi.org/10.30872 /psikostudia.v1i1.2172.

Neil, J. (2020). Domestic violence and Covid19: Our hidden epidemic. Australian journal of general practice, 49. doi:https://doi.org/10.31128/AJGP-COVID25.

Neuman, W. L. (2003). Social research methods: Qualitative and quantitative approaches. Boston, US: Allyn and Balcon.

Newby, J. M., O'Moore, K., Tang, S., Christensen, H., \& Faasse, K. (2020). Acute mental health responses during the Covid-19 pandemic in Australia. PloS one, 15(7). doi:https://doi.org/10.1371 /journal.pone.0236562.

Ningrum, P. R. (2013). Perceraian orang tua dan penyesuaian diri remaja. Ejournal psikologi fisip unmul, 1(1), 69-79.

Nurdin, H. (2004). Dasar-dasar demografi. Jakarta, ID: Fakultas Ekonomi Universitas Indonesia.

Pieh, C., O Rourke, T., Budimir, S., \& Probst, T. (2020). Relationship quality and mental health during Covid-19 lockdown. PloS one, 15(9). doi:https://doi.org/10.1371 /journal.pone.0238906.

Pinel, J. P. J. (2012). Biopsikologi. Yogyakarta, ID: Pustaka Pelajar.

Pragholapati, A. (2020). Anxiety in someone who has divorce. Bandung, ID: Universitas Pendidikan Indonesia. Retrieved from https://doi.org/10.31234/osf.io/6n4qh.

Prime, H., Wade, M., \& Browne, D. T. (2020). Risk and resilience in family well-being during the Covid-19 pandemic. American Psychologist, 75(5), 631-643. doi: https://doi.org/10.1037/amp0000660.

Putri, K. A. K., \& Sudhana, H. (2013). Perbedaan tingkat stres pada ibu rumah tangga yang menggunakan dan tidak menggunakan pembantu rumah tangga. Jurnal Psikologi Udayana, 1(1), 94-105.

Radhitya, T. V., Nurwati, N., \& Irfan, M. (2020). Dampak pandemi Covid-19 terhadap kekerasan dalam rumah tangga. Jurnal Kolaborasi Resolusi Konflik, 2(2), 1-11. doi:https://doi.org/10.24198 /jkrk.v2i2.29119.

Rahmaita, R., Pranaji, D. K., \& Yuliati, L. N. (2016). Pengaruh tugas perkembangan keluarga terhadap kepuasan perkawinan ibu yang baru memiliki anak pertama. Jurnal IImu Keluarga Dan Konsumen, 9(1), 1-10. doi:https://doi.org/10.24156/jikk. 2016.9.1.1.

Ramadhani, P. E., \& Hetty, K. (2019). Analisis dampak perceraian orang tua terhadap anak remaja. Jurnal Pekerjaan Sosial, 2(1), 109-119.

Republika. (2013). Usia pernikahan kurang dari 5 tahun rawan cerai. Retrieved from https://republika.co.id/berita/mwx7mx/usiapernikahan-kurang-dari-5-tahun-rawancerai.

Ritzer, G. (2004). Sosiologi ilmu pengetahuan berparadigma ganda. Jakarta, ID: PT RajaGrafindo Persada. 
Sbarra, D. A. (2015). Divorce and health: Current trends and future directions. Psychosomatic Medicine, 77(3), 227-236. doi:https://doi.org/10.1097/PSY.00000000 00000168.

Simanjuntak. (2007). Pokok-pokok hukum perdata Indonesia. Jakarta, ID: Pusaka Djamban.

Smyth, B. M., Moloney, L. J., Brady, J. M., Harman, J. J., \& Esler, M. (2020). Covid-19 in Australia: Impacts on separated families, family law professionals, and family courts. Family court review, 10.1111/fcre.12533. Advance online publication. doi:https://doi.org/10.1111 /fcre.12533.

Sopacua, Y. (2011). Pengaruh informasi terhadap adopsi alat KB di kalangan ibu rumah tangga pedagang kaki lima di desa Batu Merah Kota Ambon . Jurnal IImu Komunikasi, 1(2), 183-189. doi: http://dx.doi.org/10.31947/kjik.v1i2.307.
Spremo, M. (2020). Children and divorce. Psychiatria Danubina, 32(Wallerstein 1985), 353-359. doi:https://doi.org/10. 1542/pir.1-7-211.

Stanley, S. M., \& Markman, H. J. (2020). Helping couples in the shadow of Covid19. Family process, 59(3), 937-955. doi: https://doi.org/10.1111/famp.12575.

Sugiyono. (2017). Statistik untuk penelitian. Bandung, ID: Alfabeta.

Suhendi \& Wahyu, R. (2001). Pengantar studi sosiologi keluarga. Bandung, ID: Pustaka Setia.

Surya, M. (2009). Bina keluarga. Bandung, ID: Graha IImu.

Wongkaren, T. (2000). Di negara barat, fertilitas tidak lagi terkait dengan perkawinan. Warta Demografi, 30(2), 8-10.

Yatimah, D. (2017). Landasan pendidikan. Jakarta, ID: CV. Alumgadan Mandiri. 